\title{
High Pressure Electron Gun for Electron Beam Welding and Additive Manufacturing
}

\author{
Cooperative Research and Development Agreement \\ Final Report
}

CRADA Number: FRA-2019-0051

Fermilab Technical Contact: Charles Thangaraj

Summary Report

13 August 2021

Fermi National Accelerator Laboratory / Kirk and Pine Street / P.O. Box 500 / Batavia, IL 60510 / 630.840.3000 / www.fnal.gov / fermilab@fnal.gov Managed by Fermi Research Alliance, LLC for the U.S. Department of Energy Office of Science 


\section{NOTICE}

This report was prepared as an account of work sponsored by an agency of the United States government. Neither the United States government nor any agency thereof, nor any of their employees, makes any warranty, express or implied, or assumes any legal liability or responsibility for the accuracy, completeness, or usefulness of any information, apparatus, product, or process disclosed, or represents that its use would not infringe privately owned rights. Reference herein to any specific commercial product, process, or service by trade name, trademark, manufacturer, or otherwise does not necessarily constitute or imply its endorsement, recommendation, or favoring by the United States government or any agency thereof. The views and opinions of authors expressed herein do not necessarily state or reflect those of the United States government or any agency thereof.

Available electronically at http://www.osti.gov/

Available for a processing fee to U.S. Department of Energy and its contractors, in paper, from:

U.S. Department of Energy

Office of Scientific and Technical Information

P.O. Box 62

Oak Ridge, TN 37831-0062

phone: 865.576 .8401

fax: 865.576 .5728

email: mailto:reports@osti.gov

Available for sale to the public, in paper, from:

U.S. Department of Commerce

National Technical Information Service

5301 Shawnee Rd

Alexandria, VA 22312

phone: 800.553 .6847 or $703-605-6000$

fax: 703.605.6900

email: orders@ntis.gov

online ordering: http://www.ntis.gov/ 
In accordance with Requirements set forth in Article XI.A(3) of the CRADA document, this document is the final CRADA report, including a list of Subject Inventions, to be forwarded to the Office of Science and Technical Information as part of the commitment to the public to demonstrate results of federally funded research.

CRADA number: $\quad$ FRA-2019-0051

CRADA Title: $\quad$ High Pressure Electron Gun for Electron Beam Welding and Additive Manufacturing

Parties to the Agreement: U.S. Electron, Inc. and Fermi Research Alliance, LLC

Sponsoring DOE Program Office(s): Office of Science - HEP

DOE Funding Commitment Table: N/A

\begin{abstract}
CRADA work:
Electron beam welding is a premier technology for high quality welding. However, e-beam welding is viewed as very expensive method for quality results. Therefore, it is often the last choice for joining metals. U.S. Electron is developing a technology that changes the welding environment. As a result of this pursuit of technology, e-beam welding can be field deployable. U.S. Electron has received a DOE SBIR Phase I grant to demonstrate a proof of principle that the plasma cathode can be installed in an electron gun housing, generate a current and energy enough to weld stainless steel. Under this CRADA, Fermilab proposed to provide a power supply, the necessary safety expertise and the physical location for testing of the initial prototype equipment developed by U.S. Electron.
\end{abstract}

\title{
Summary of Research Results:
}

After receiving the Phase I SBIR award, U.S. Electron, Inc. approached Fermilab to request a safe technical space for testing as well as a suitable power supply fitting the project's technical requirements. Fermilab, as one of few laboratories with the appropriate facilities, agreed to support the work and chose to host the testing at the Heavy Assembly Building (HAB) where a suitable shielding enclosure per the Partner's specifications could be built.

U.S. Electron and Fermilab made a good faith effort to set up the test assembly in accordance with U.S. Electron's experimental run plan. Unfortunately, the project could not be completed as originally envisioned, so there are no research results to report from this CRADA.

Initial delays at U.S. Electron in preparation for the testing, technical changes in the specifications for the necessary power supply, site-access delays at Fermilab due to the COVID pandemic, and complexities associated with testing at Fermilab in accordance with site safety requirements pushed the timeline and expected costs beyond the original project scope. As a result, the CRADA was terminated early by mutual agreement of both parties. 
Related Reports, Publications, and Presentations:

N/A

Subject Inventions listing:

N/A

Report Date: 13 August 2021

Technical Contact at Fermilab: Charles Thangaraj, jtobin@fnal.gov

Partner POC Name and Email Address: John Noonan, noonan@uselectron.com

This document contains NO confidential, protectable or proprietary information. 